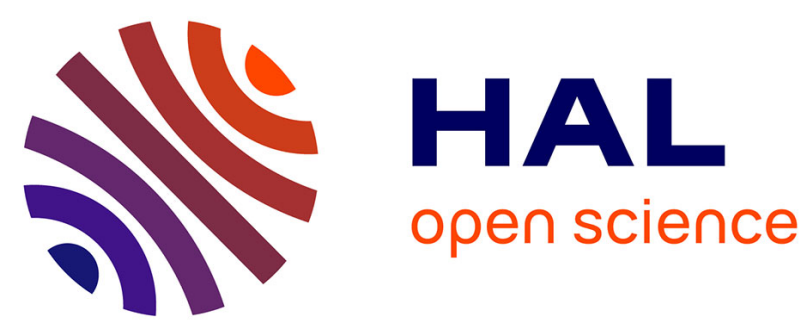

\title{
Six fatal cases of classical rabies virus without biting incidents, Iran 1990-2010.
}

Susan Simani, Ahmad Fayaz, Pooneh Rahimi, Naser Eslami, Nader Howeizi, Peyvand Biglari

\section{- To cite this version:}

Susan Simani, Ahmad Fayaz, Pooneh Rahimi, Naser Eslami, Nader Howeizi, et al.. Six fatal cases of classical rabies virus without biting incidents, Iran 1990-2010.. Journal of Clinical Virology, 2012, 54 (3), pp.251-254. 10.1016/j.jcv.2012.03.009 . pasteur-00751271

\section{HAL Id: pasteur-00751271 https://hal-riip.archives-ouvertes.fr/pasteur-00751271}

Submitted on 13 Nov 2013

HAL is a multi-disciplinary open access archive for the deposit and dissemination of scientific research documents, whether they are published or not. The documents may come from teaching and research institutions in France or abroad, or from public or private research centers.
L'archive ouverte pluridisciplinaire HAL, est destinée au dépôt et à la diffusion de documents scientifiques de niveau recherche, publiés ou non, émanant des établissements d'enseignement et de recherche français ou étrangers, des laboratoires publics ou privés. 
Provided for non-commercial research and education use. Not for reproduction, distribution or commercial use.

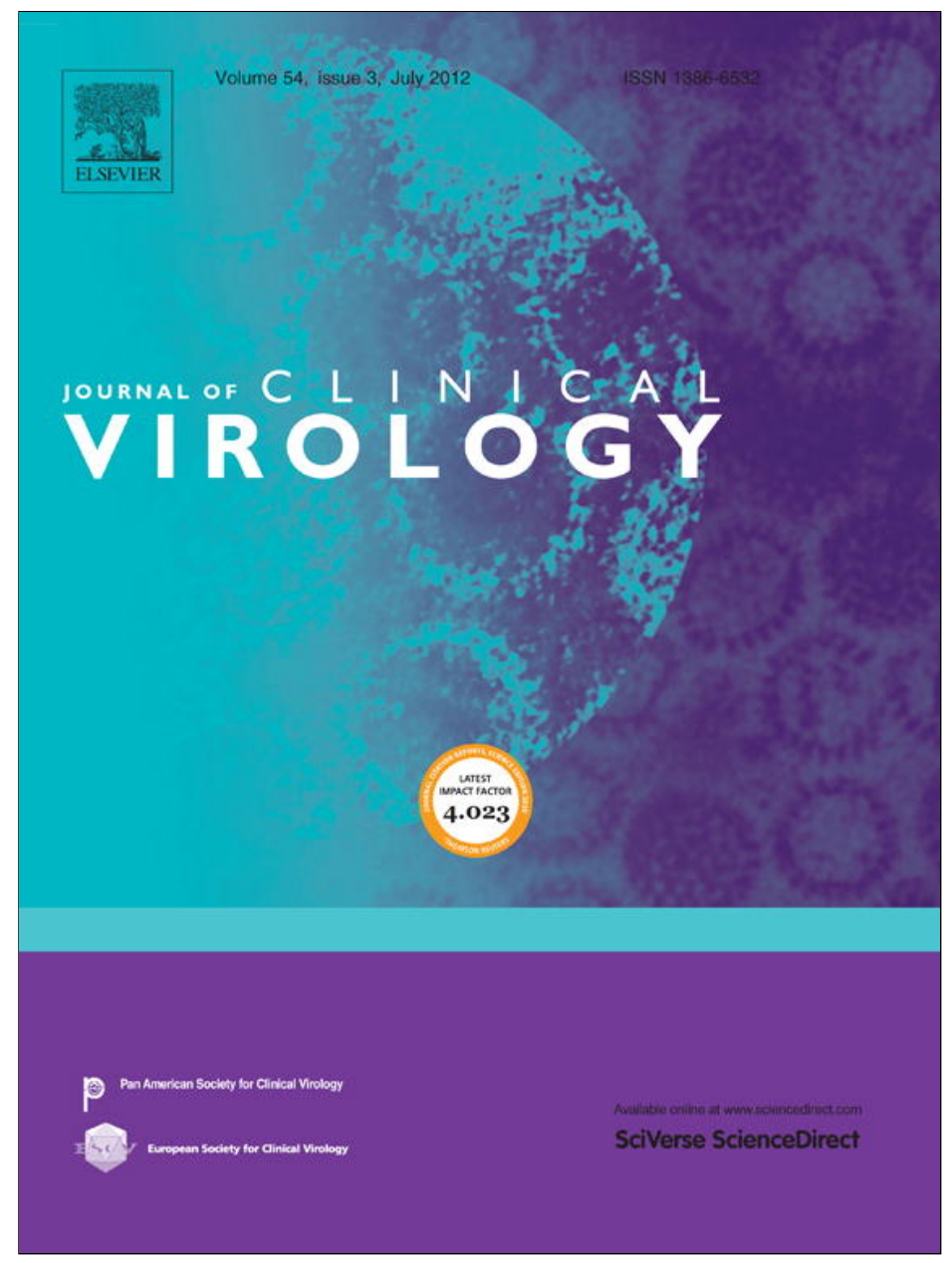

This article appeared in a journal published by Elsevier. The attached copy is furnished to the author for internal non-commercial research and education use, including for instruction at the authors institution and sharing with colleagues.

Other uses, including reproduction and distribution, or selling or licensing copies, or posting to personal, institutional or third party websites are prohibited.

In most cases authors are permitted to post their version of the article (e.g. in Word or Tex form) to their personal website or institutional repository. Authors requiring further information regarding Elsevier's archiving and manuscript policies are encouraged to visit:

http://www.elsevier.com/copyright 


\title{
Six fatal cases of classical rabies virus without biting incidents, Iran 1990-2010
}

\author{
Susan Simani, Ahmad Fayaz, Pooneh Rahimi*, Naser Eslami, Nader Howeizi, Peyvand Biglari \\ WHO Collaborating Center for Reference and Research on Rabies, Institute Pasteur, 12 Farvardin Ave., Enghelab Square, Tehran, Iran
}

\section{A R T I C L E I N F O}

\section{Article history:}

Received 10 September 2011

Received in revised form 7 March 2012

Accepted 28 March 2012

\section{Keywords:}

Rabies infection

Non-bite rabies transmission

Rabies post-exposure prophylaxis

\begin{abstract}
A B S T R A C T
Background: Rabies is an endemic fatal zoonotic disease, commonly transmitted to humans through contact (bites and scratches) with infected animals.

Objectives: During the years 1990-2010, six patients with the clinical symptoms of rabies (fever, tinnitus, buzzing, delirium and hydrophobia), with no history of a bite, were diagnosed by physicians in Iran. To obtain laboratory confirmation of rabies infection, different clinical specimens from each patient were sent to the World Health Organisation (WHO) Collaborating Center for Reference and Research on Rabies, Pasteur Institute of Iran.

The first case was a 39-year-old male veterinary technician who entered his uncovered scratched hand into the mouth of a rabid bovine and became infected. Two years later, a herd of sheep being tended by a shepherd and his two sons were attacked by a rabid wolf. All three individuals were infected when they applied burnt thorny wool to the sheep's wounds as a bandage. Their hands were scratched and then infected through contact with the remaining saliva of the rabid wolf on the sheep's wounds. In 1994, two other human cases occurred through corneal transplantation from the same donor who had died with the clinical signs of food poisoning (according to his hospital record), which probably was a misdiagnosis of rabies infection.
\end{abstract}

Study design: This is a case series study that describes human rabies cases without biting incidents. According to the WHO recommendation, human rabies cases are notifiable, therefore, in Iran, a rabies surveillance system has been established to follow these cases. During the last decade, six patients with no 'history of a bite' were hospitalised with growing symptoms of rabies. The data were collected from each patient by the physicians and transferred to the Ministry of Health and Medical Education of Iran, and to the WHO Collaborating Center for Reference and Research on Rabies, Pasteur Institute of Iran as the only testing laboratory. Thus, they came to the attention of the surveillance system. Ante-mortem diagnosis was performed on saliva, cerebrospinal fluid and blood samples that were collected from the first patient by the physicians. Fresh brain specimens from all patients were kept in a mixture of $50 \%$ glycerol in phosphate-buffered saline and transported on ice to the WHO Collaborating Center for Reference and Research on Rabies.

Results: For the first patient, rabies virus was investigated in saliva using the rapid tissue cell inoculation test (RTCIT) and the mouse inoculation test (MIT). Anti-rabies antibodies in this patient's serum and cerebrospinal fluid (CSF) were examined using the mouse neutralisation test (MNT). Fresh brain specimens from all patients were examined using the fluorescence antibody test (FAT) as recommended by the WHO laboratory manual in rabies as the post-mortem diagnostic test for rabies. Rabies infection was confirmed in all of the deceased patients. Anti-rabies antibodies were identified only in one patient's serum specimen. Testing also showed that the rabies virus isolated was the classic rabies virus (serotype 1), which is widespread in Iran.

Conclusions: Prevention and control of this fatal disease require a sensitive surveillance system to follow 'suspected' animal and human rabies cases thoroughly through the improved reporting system, which contains the history of exposure, clinical examinations, symptoms and laboratory results. This study describes some notable human rabies infections and their transmission modes to prevent occupational accidents.

(C) 2012 Elsevier B.V. All rights reserved.

Abbreviations: WHO, World Health Organization; RID, rabies immune globulin; CSF, cerebrospinal fluid; PK, penetrating keratoplasty; LK, lamellar keratoplasty; IF, indirect immunofluorescence; RTCIT, rabies tissue culture infection test; MIT, mouse inoculation test; MNT, mouse neutralisation test; PrEP, pre-exposure prophylaxis.

* Corresponding author. Tel.: +98 2166403496; fax: +98 2166480777.

E-mail addresses: prahimi@pasteur.ac.ir, prahimi@razi.tums.ac.ir (P. Rahimi). 


\section{Background}

Rabies is an acute viral zoonotic disease that causes encephalitis in mammals. ${ }^{1-3}$ It is estimated that there are approximately 55000 victims per year of whom $30-50 \%$ are under 15 years of age. $^{3-5}$ Although rabies is usually fatal after the onset of neurological symptoms, prompt wound care, administration of rabies immune globulin (RIG) and vaccine are nearly $100 \%$ effective in preventing human rabies following exposure. ${ }^{3-6}$ The rabies virus (genus Lyssavirus, family Rhabdoviridae) is present in the saliva of infected mammals and most commonly is transmitted via a biting incident. ${ }^{5,6}$ However, contamination of mucous membranes with other potentially infectious materials (such as brain tissues, tracheal and nasal secretions, tears and CSF) through scratches or, in very rare conditions, corneal transplantation or exposure of membranes to aerosols have been documented as cases of non-bite rabies transmission. ${ }^{5,7-13,16}$ Inhalation of aerosolised rabies virus resulted in the deaths of two laboratory technicians and two other individuals in Frio Cave in Texas. ${ }^{7,9,13,14,16}$ Documentation of these cases is important to increase awareness among clinicians about rabies risk and modes of transmission. $., 7-13,16$

\section{Objectives}

In this study, we describe transmission of classical rabies in six fatal cases without biting incidents in the disease history, which occurred during the years 1990-2010 in Iran. Our goal is to raise awareness among clinicians about rabies risk and modes of transmission.

\section{Study design}

In Iran, rabies surveillance system including the Ministry of Health and Medical Education, and as the only testing laboratory in Iran, WHO Collaborating Center for Reference and Research on Rabies, has been established to follow rabies cases. These patients were hospitalised with growing symptoms of rabies, examined by the physicians and their history was collected and transferred to the Ministry of Health and Medical Education of Iran and to the WHO Collaborating Center for Reference and Research on Rabies, and therefore, they came to the attention of the surveillance system.

In 1990, an unvaccinated 39-year-old veterinary staff in Aligoudarz (Lorestan province, western Iran) inserted his uncovered abraded hand into the mouth of a rabid bovine. Despite his knowledge about rabies transmission, he had not followed safety rules. Unfortunately, his contact with the saliva of that rabid bovine was not considered as an exposure by him, so he did not receive post-exposure prophylaxis.

Forty days later, symptoms including itching, tinnitus and buzzing, followed by others similar to those of influenza, caused him to check into the emergency department. The physicians suspected the flu and injected him with antibiotics. On the next day, the symptoms developed into fever, delirium and hydrophobia. Although he suspected rabies infection, his self-diagnosis was not accepted by his physicians. He was hospitalised twice in the infectious ward and twice in psychiatric clinics. The symptoms gradually worsened and he died 16 days after the onset of rabies symptoms.

Brain tissue samples were collected from this deceased patient by well-trained local staff. The specimens were kept in a mixture of $50 \%$ glycerol in phosphate-buffered saline (PBS) and sent to the WHO Collaborating Center for Reference and Research on Rabies, Pasteur Institute of Iran for post-mortem diagnosis according to the WHO-recommended laboratory techniques in rabies including direct immunofluorescence (fluorescent-antibody technique (FAT)) for direct rabies diagnosis. In this test, smears prepared by the impression method from the samples of brain tissue were air dried and fixed in high-grade cold acetone and then stained with a drop of specific conjugate using anti-rabies nucleocapsid conjugate (Bio-Rad, France). We also performed a rabies tissue culture infection test (RTCIT) using neuroblastoma cell lines (CCL-131). The cells were grown in Dulbecco's modified Eagle's medium (DMEM) with $5 \%$ foetal calf serum (FCS) and incubated at $36^{\circ} \mathrm{C}$ with $5 \% \mathrm{CO}_{2}$. After incubation for up to 4 days, the presence of rabies virus in the cells was assessed by the FAT. A mouse inoculation test (MIT) ${ }^{17-22}$ was also performed on the brain tissue specimen of this patient, using 5-10 mice, each 3-4 weeks old (12-14 g), that were inoculated intracerebrally. The inoculum was the clarified supernatant of a $20 \%(\mathrm{w} / \mathrm{v})$ homogenate of brain material in an isotonic buffered solution containing antibiotics. To reduce animal pain, mice were anaesthetised using ethoxyethane (diethyl ether) when inoculated. The young adult mice were observed daily for 28 days, and every dead mouse was examined for rabies using the FAT. ${ }^{18}$

In 1992, three human rabies cases were observed in Torbat-jam (Khorasan province north-eastern Iran). The patients were shepherds (a father and his two sons: 8 and 12 years old) whose herd had been attacked by a rabid wolf, which wounded many of the sheep. They implemented the traditional method of applying burnt wool to the wounds to bandage them. After 20 days, neurological symptoms of rabies infection developed and they were diagnosed by specialists in the hospital. The shepherd and his two sons subsequently died. Again, brain tissue samples were collected from them and the process described above was performed on the specimens. A copy of their hospital records was also received by the WHO Collaborating Center for Reference and Research on Rabies, Pasteur Institute of Iran.

In 1994, two human-to-human rabies transmissions occurred following corneal transplantation.

In March 1994, a 40-year-old man was hospitalised at Labbafinejad Medical Center for corneal transplantation due to the advanced keratoconus. The donor was a 20 -year-old man who was thought to have died of food poisoning (the diagnosis is suspected to be incorrect but it had been recorded as the cause of his death). Penetrating keratoplasty (PK) was performed on the 40-year-old patient under general anaesthesia without any complications. The patient was discharged 2 days after the surgery. During the following 20 days, he was examined a few times with no significant findings. On the same day as his surgery, a 35-year-old man underwent lamellar keratoplasty (LK) for his gelatinous droplet dystrophy (left eye), which was performed by the same surgeon. The cornea was from the same donor and 3 weeks after LK, the eye was unremarkable. Twenty-six days after PK, the first patient was hospitalised in another hospital with nausea and paraesthesia of his lips. He developed hydrophobia and, on the next day, he died. Rabies was suspected as the cause of his death by his physicians. Initially, it was thought that he has been infected through his work as a veterinarian. A post-mortem diagnosis was performed on brain tissue sample sent in a mixture of 50\% glycerol in PBS to the WHO Collaborating Center for Reference and Research on Rabies, Pasteur Institute of Iran. FAT, RTCIT and MIT were performed according to the WHO-recommended laboratory techniques. ${ }^{18}$

Forty days later, the second patient was admitted to the hospital because of vomiting and weakness. Taking into consideration the death of the first patient and that the donor was the same for both of these recipients, rabies was thought to be the cause. Saliva, blood and CSF samples were collected immediately and sent to the WHO Collaborating Center for Reference and Research on Rabies, Pasteur Institute of Iran. An ante-mortem diagnosis of rabies virus was performed using the MIT as described previously, and the mouse neutralisation test (MNT). ${ }^{18}$ To perform the MNT on serum sample and CSF, the challenge virus strain (CVS) used in this study was titrated at $10^{-7}$, as described by Kaplan. ${ }^{18}$ A constant dose of 
Table 1

Laboratory results of clinical specimens from six rabies human cases in Iran (1990-2010).

\begin{tabular}{|c|c|c|c|c|c|c|c|c|c|}
\hline \multirow{2}{*}{$\begin{array}{l}\text { Number of patient } \\
\text { Type of specimen }\end{array}$} & \multirow{2}{*}{$\begin{array}{l}1 \\
\text { Brain }\end{array}$} & \multirow{2}{*}{$\begin{array}{l}2 \\
\text { Brain }\end{array}$} & \multirow{2}{*}{$\begin{array}{l}3 \\
\text { Brain }\end{array}$} & \multirow{2}{*}{$\begin{array}{l}4 \\
\text { Brain }\end{array}$} & \multirow{2}{*}{$\begin{array}{l}5 \\
\text { Brain }\end{array}$} & \multicolumn{4}{|l|}{6} \\
\hline & & & & & & Brain & Saliva & CSF & Serum \\
\hline \multicolumn{10}{|l|}{ Results of laboratory methods } \\
\hline FAT & + & + & + & + & + & + & & & \\
\hline RTCIT & + & + & + & + & + & + & + & & \\
\hline MIT & + & + & + & + & + & & + & & \\
\hline MNT & & & & & & & & - & + \\
\hline Monoclonal antibody test & & & & & & & & & $+($ serotype 1$)$ \\
\hline
\end{tabular}

FAT: fluorescence antibody test; RTCIT: rapid tissue culture infection test; MIT: mouse inoculation test; MNT: mouse neutralization test.

titrated virus was added to the sera, which were serially diluted at $1 / 5$. A reference serum of known titre was included in the assay. The virus/serum mixtures at dilutions of $1 / 5,1 / 25,1 / 125$ and 1/625 were then injected intracerebrally into the groups of 10 young adult mice. In total, 40 mice were inoculated with the virus/serum mixtures. The percentage of mortality was determined and the serum dilution that protects $50 \%$ of the animals was calculated by the Reed and Muench method. ${ }^{18}$ This patient died and his brain tissue sample was tested by using the FAT, and the RTCIT. ${ }^{18}$ Due to the positive results, 14 hospital personnel and 50 of the patient's colleagues and family members received post-exposure prophylaxis.

To identify the serotype of virus isolated from this patient, monoclonal antibody testing was performed. ${ }^{17,18}$

\section{Results}

Rabies virus was detected in brain tissue sample from the first patient using the FAT, the RTCIT and the MIT. So, earlier clinical diagnosis of rabies was confirmed. Rabies infection was identified in brain tissue samples from the shepherd, his two sons and the first corneal recipient using the FAT, RTCIT and MIT methods according to the WHO laboratory techniques for rabies as described previously. ${ }^{18}$

Ante-mortem diagnosis was performed in saliva, CSF and serum specimens from the last patient. The results of RTCIT and MIT in saliva were positive. The anti-rabies antibody was detected at titre of $0.3 \mathrm{IU} \mathrm{ml}^{-1}$ in the serum sample using the MNT test. ${ }^{18}$ MNT test on CSF and serum specimens was negative. The serotype of virus isolated from this patient was identified using the monoclonal antibody testing, ${ }^{17,18}$ and it was revealed that the isolated virus was the classic rabies virus (serotype 1 ), which is the most common rabies virus serotype in Iran.

Positive results were obtained in post-mortem diagnosis on brain tissue sample from this patient using the FAT and RTCIT. The laboratory results are depicted in Table 1.

\section{Discussion}

Rabies is one of the most neglected diseases in developing countries, especially in poor rural communities. Despite the availability of safe and effective human vaccines, human rabies victims continue to increase in many countries., ${ }^{2,15,16,21,22}$ Rabies transmission occurs mainly through the bite of a rabid animal, and saliva is the major source of virus spread., ${ }^{4,5,7,9}$ Rabies surveillance depends on reporting of the number of laboratory-confirmed human rabies cases through the structures of the World Health Organization. ${ }^{3-5,8,11}$ Human rabies is preventable by performing pre-exposure prophylaxis (PrEP),which is highly recommended for all rabies laboratory staff, veterinarians and veterinary technicians, and by increased awareness among people, who may be exposed, especially those in rural areas. $5,6,10-12$ Lack of adequate information about the importance of following safety rules should be considered as one of the main obstacles to reducing the incidence of human rabies. ${ }^{8,16}$ The unvaccinated veterinary technician discussed above exposed his uncovered abraded hand to the saliva of a rabid bovine and he did not refer himself for post-exposure prophylaxis. The shepherds with no definite history of animal bite were infected due to a lack of awareness about the modes of rabies transmission and PrEP. Although rabies post-exposure prophylaxis is available, nationwide in Iran, these occurrences indicate that awareness of rabies needs to be increased through the regular assessment of the knowledge, attitudes and practices in the general population and among clinicians. This information can be used to design appropriate rabies prophylaxis educational programmes according to the guidelines provided by the World Health Organization and the Advisory Committee on Immunization Practices for the treatment of rabies caused by animal bites. ${ }^{17,21,22}$ This report provides a better understanding of potential non-bite routes of transmission, and should encourage policy-makers to find ways to increase the general knowledge about the widespread extent of the disease and the risk of transmission in the population and among medical practitioners. One important mode of non-bite transmission is person-to-person via organ transplantation, in particular corneal transplants. 4,6,7,9,12,13,15 Such transmission has occurred in eight recipients in five countries: Thailand (two cases), India (two cases), Iran (two cases), the United States (one case) and France (one case). ${ }^{12,15,17}$ Eye banks can play a major role in reducing the possibility of rabies transmission through stringent guidelines for the acceptance of cornea donors. ${ }^{13,15,16,21}$ The two cases discussed in this report occurred accidentally, and they led to the screening of donor corneas for rabies using FAT in the WHO Collaborating Center for Reference and Research on Rabies, Pasteur Institute of Iran. In Iran, each suspected human rabies case must be laboratory confirmed in the WHO Collaborating Center for Reference and Research on Rabies, Pasteur Institute of Iran. According to the confirmed human rabies cases, similar incidents have not occurred in 20 years in Iran, most likely because of an elevated awareness of such risks.

\section{Funding}

None.

\section{Competing interests}

None declared.

\section{Ethical approval}

Not required.

\section{Acknowledgement}

We wish to acknowledge laboratory staff in the WHO Collaborating Center for Reference and Research on Rabies, Institute Pasteur, Tehran, Iran for their participation in this study. 


\section{References}

1. Lyles DS, Rupprecht CE. Rhabdoviridae. In: Knipe D, Howley P, et al., editors. Fields virology. 5th ed. Philadelphia: Lippincott, Williams, \& Wilkins; 2007. p. 1363-408.

2. Lafon M. Mini-review. The rabies virus. Rabies virus receptors. J Neurovirol 2005;11:82-7.

3. Jackson AC, Wunner WH. Rabies. 2nd ed; 2007, ISBN 978-012-369366-2. Copyright Elsevier Inc.

4. Chang HG, Eidson M, Noonan-Toly C, et al. Public health impact of reemergence of rabies, New York. Emerg Infect Dis 2002;8:909-13.

5. World Health Organization. Guide for rabies pre and post-exposure prophylaxis in humans. Department of Neglected Tropical Diseases - Neglected Zoonotic Diseases Team; 2010.

6. Rupprecht CE, Briggs D, Brown C, et al. Evidence for a 4-dose vaccine schedule for human rabies post-exposure prophylaxis in previously non-vaccinated individuals. Vaccine 2009;27:7141-8.

7. Dutta JK. Rabies transmission by oral and other non-bite routes. J Indian Med Assoc 1998;96:359.

8. Bourhy H, Varsat AD, Hotez PJ, Salomon J. Rabies, still neglected after 125 years of vaccination. PLoS Negl Trop Dis 2010;4(11):e839, http://dx.doi.org/10.1371/journal.pntd.0000839.

9. Schoenstadt A. Health information brought to life, rabies transmission. Available at: http://rabies.emedtv.com/rabies/rabies-transmission.html.

10. Fayaz A. Report of WHO collaborating center for reference and research on rabies to WHO-EMRO; 1990

11. World Health Organization. WHO expert committee on rabies. 8th report. WHO technical report series, no. 824. Geneva, Switzerland; 1992.
12. CDC. Human rabies prevention-United States 2008. Recommendations of the Advisory Committee on Immunization Practices (ACIP). MMWR Recomm Rep 2008;57(RR-3):1-28.

13. Javadi MA, Fayaz A, Mirdehghan SA, Ainollahi B. Transmission of rabies by corneal graft. Cornea 1996;15(4):431-3.

14. Warrell MJ. Emerging aspects of rabies infection: with a special emphasis on children. J Clin Microbiol 2008;21(3):251-7.

15. Johnson N, Lipscombe DW, Stott R, et al. Investigation of a human case of rabies in the United Kingdom. J Clin Virol 2002;25:351-6.

16. Dacheux L, Wacharapluesadee S, Hemachudha Th, et al. More accurate insight into the incidence of human rabies in developing countries through validated laboratory techniques. PLoS Negl Trop Dis 2010;4(11):e765 http://dx.doi.org/10.1371/journal.pntd.0000765.

17. World Health Organization. WHO expert consultation on rabies. 1 st report. WHO technical report series, no. 931. Geneva, Switzerland; 2005.

18. Meslin FX, Kaplan MM, Koprowski H, editors. Laboratory techniques in rabies. 4 th ed. Geneva: World Health Organization; 1996. p. 53-93.

19. Woldehiwet $Z$. Clinical laboratory advances in the detection of rabies virus. Clin Chim Acta 2005;351:49-63.

20. Dürr S, Naïssengar S, Mindekem R, et al. Rabies diagnosis for developing countries. PLoS Negl Trop Dis 2008;26:e206.

21. Fooks AR, Johnson N, Freuling CM, Wakeley PR, Banyard AC. Emerging technologies for the detection of rabies virus: challenges and hopes in the 21st century. PLoS Negl Trop Dis 2009;3(9):e530, http://dx.doi.org/10.1371/journal.pntd.0000530.

22. Rupprecht CE, Barrett J, Briggs D, Cliquet F, Fooks AR, Lumlertdacha B, et al. Can rabies be eradicated? Dev Biol (Basel) 2008;131:95-121. 